\title{
Comments on Larry May's Limiting Leviathan, Hobbes on Law and International Affairs
}

\author{
Eleanor Curran \\ Kent Law School, Eliot College, \\ University of Kent, Canterbury, Kent C 2 7NS \\ e.a.curran@kent.ac.uk
}

\begin{abstract}
Larry May makes some important arguments about Hobbes on law and particularly about the significance of the notion of equity for Hobbes, both as a moral law and as a (possibly limiting) requirement of a sovereign's lawmaking authority. I am generally supportive of May's project while remaining sceptical about the conclusion that a selfrestraining sovereign is a genuinely limited sovereign.
\end{abstract}

\section{Keywords}

Law - rule of law - limited sovereignty - moral law

\section{Introduction}

This is an interesting and important book on Hobbes's writing on the law which I enjoyed reading and learned a great deal from. I should also say that I am sympathetic to Larry May's view that, despite Hobbes's many arguments and remarks that seem to favour or support absolutism, there is some important sense in which he is a less than convincing absolutist. As May says; 'Hobbes's views are both more complex and more palatable' (p. 18) than they are often seen to be.

I will restrict my comments to the arguments concerning: sovereignty and the limitation of sovereignty, Hobbes's legal theory, the relationship between law and morality for Hobbes and some of the arguments about equity. 
May starts by stating that the thesis of the book is that 'Hobbes is much more amenable to moral, and even legal limits on law-making - indeed closer to Lon Fuller than to today's legal positivists - than he is often portrayed.' (p. 1) He adds, that to support this thesis he will argue, that Hobbes places greater weight on equity than on justice, and that understanding the role of equity is the key to his legal philosophy.' Further, he will argue that '[e]quity ... is the moral concept that provides restrictions on what a sovereign can legitimately do,' (ibid.).

\section{Sovereignty - Limitations of}

May starts by granting a lot to the other side of the argument. 'Hobbes is relatively clear in saying that there are no substantive limits on sovereignty and that there should not be any, since the sovereign needs to be as strong as possible in order to secure the peace' (p. 3) May interprets 'substantive' limits to mean limits by subjects or citizens who could restrict what the sovereign does. But he says there are other sorts of limitation that would not weaken the sovereign in this way.

May says 'Hobbes followed Bodin in thinking that sovereignty was not properly so called when it was divided.' And he continues, 'I will argue that Hobbes clearly disfavoured divided sovereignty (at least in Leviathan) but ... Hobbes did agree that sovereignty could and should be limited.' (p. 23)

How then, is sovereignty limited, according to May? He sets out five types of limitation on sovereign law-making power: moral limitations, prudential limitations (many would argue, of course, that these are the same for Hobbes), legal and structural limitations, international limitations and self-limitations. The important ones, for the arguments I want to discuss, are the moral limitations.

\section{Moral Limitations}

Morality, for Hobbes, is set out in the laws of nature, as he says 'the Science of these Lawes, is the true Morall Philosophy' (Lev., Ch 15, Squib, p. 215.) And May argues that the main evidence for saying that morality limits legality 'comes from the fact that all of the laws of nature, ... are said still to be binding after the institution of sovereignty.' (p. 4) The textual evidence for this includes Hobbes's infamously puzzling declaration, that 'the Law of Nature and the Civill Law, contain each other, and are of equall extent.' And then, the statement that while in the state of nature they 'are not properly Lawes, but qualities that 
dispose men to peace, and to obedience.' But, '[w] hen a Common-wealth is once settled, then are they actually Lawes, and not before; as being then the commands of the Commonwealth.' (Lev., Ch 26, p. 314). This does seem clear, that Hobbes argues that the sovereign must give the laws of nature the status of laws proper once he has the sovereign power. And this also links with what Hobbes has said in Chapter 15, that 'the Lawes of Nature oblige in Conscience alwayes but in Effect then onely when there is Security' (Lev., Ch. 15, squib, p. 215). May's next point is that 'some of these laws of nature, especially equity, bind the sovereign'. (p. 4)

Again, there is good textual evidence for this. But the more difficult question is in what sense are the laws of nature binding for the sovereign? For Hobbes also says, just after the passage quoted above from Chapter 26 , 'to make them binding, there is need of the Ordinances of Soveraign Power,' (Lev., Ch. 26, p. 314) In what sense then, can they bind the sovereign himself?

May argues that, first, 'when something binds in conscience it is truly binding' (p. 5) and second, that the laws of nature (particularly equity) form the basis for the duties of the sovereign as set out in Chapter 30. (ibid.) It is there that Hobbes links the duty to be equitable to the fundamental duty of the sovereign to provide for the safety of the people. 'The safety of the people, requireth further from him, or them that have the sovereign power, that justice be equally administered to all degrees of people; ... for in this consisteth equity, to which, as being a precept of the law of nature, a sovereign is as much subject, as any of the meanest of his people. (Lev Ch. 30, quoted in May, p. 6)

May then argues that 'for Hobbes, even the bindingness of equity is grounded in prudence. The sovereign should not violate the principle of equity, because to do so would risk the kind of open warfare that would jeopardize sovereignty by undermining the sovereign's ability to ensure the safety of the people.' (p. 41) This, says May, provides a moral limit on law-making in the sense that when (and only when) the immoral actions of the law-maker jeopardize that which grounds sovereignty, then there enters a limiting constraint on the law. (p. 41) We might call this a pragmatic argument for restraint. But it raises an old problem in Hobbes scholarship, which is, how should we understand his moral theory? If we see it as purely prudential can it be said to be truly referring to morality at all? If not, then we do not have an argument about moral limits on sovereign law-making but rather just prudential limits. This, in my view, is one of the shortcomings of this part of the argument. It is very reliant on arguments about Hobbes's moral theory and as such runs the risk of becoming mired in the controversies that surround that theory.

May argues that 'the moral limits on sovereign law-making are largely drawn in procedural terms by Hobbes: ruling out laws that are superfluous, 
contradictory, or secret, as well as laws that cause citizenry to lose faith in the fairness of the law. ' $[\mathrm{A}]$ ny laws that have the effect of undermining peace are ones that the sovereign is prohibited from promulgating by the principles of equity ...' (p. 41) May has made a strong case for the claim that Hobbes does think that there are at least some moral limitations on sovereign law-making, despite my more general misgivings about the disadvantages of relying on arguments about his moral theory.

\section{Equity}

May argues, rather ingeniously, that what Hobbes loses with his impoverished notion of justice as pure legality, devoid of any normative content, he regains with his broadened and rich version of equity, which goes beyond a mere procedural rule of equal treatment to encompass fairness itself. And so the normative content that was lost to justice is recovered and found instead in the notion of equity. And further, May argues, 'equity not justice, is the dominant moral category in Hobbes's political and legal philosophy.' (ibid.)

Given that the Hobbesian sovereign does not have any legal duties as such, being outside the social contract, May concludes that 'his duties must, in some sense or other, be "natural" duties. (p. 68) And he draws on a remark in De Cive to set up the argument. 'Now all the duties of the sovereign are contained in this one sentence, the safety of the people is the supreme law' (De Cive, Ch. XIII, quoted in May, p. 68). As safety is defined very broadly for Hobbes, including everything necessary for a commodious life, May connects the duty to the sovereign's acceptance of the power and authority granted him by the people, and this includes accepting that he must guarantee the peace. May has already argued that this amounts to what he terms a constitutional limitation on the sovereign; once he fails to keep the peace, the contract is dissolved and he loses the right to rule. Equity, which May argues is the prime law of nature, adds a moral limitation on the exercise of rulership. Drawing on what Hobbes says in A Dialogue ..., about the Equity courts, he also argues that this moral limitation is one of substance rather than purely procedural. Equity provides the standard by which law can be judged to be good or bad by judges and by the king 'and concerns whether they have correctly interpreted or applied the law.' (p. 8o) In Leviathan Hobbes says 'The things that make a good judge, or good interpreter of the laws, are first a right understanding of that principle law of nature called equity,' (p. 82). In the Dialogue, May says that Hobbes explicitly states that laws cannot be unreasonable and implies that laws cannot be capricious or superfluous and that all this follows from the principle of 
equity. This extension of the scope of equity, argues May, creates limitations on what the law-maker can declare to be law that 'verge into being substantive limitations' (p. 83).

He has shown that for Hobbes, moral limitations, provided by the law of nature that is equity, restrict what laws the sovereign can make. This limitation, he claims, binds the law-maker in a moral way, at least in his conscience. And with this last phrase, the carefully constructed arguments of the chapter are in danger of unravelling, in my view. At the moment a sovereign is told that such limitations bind him in conscience only, I can see the malevolent grin of the dictator return.

\section{Legal Theory - Hobbes not a strict positivist}

May made the argument that Hobbes is not a strict legal positivist when he claimed that there are some moral strictures on law-making. When Hobbes grants that 'it is true that they that have the sovereign power may commit iniquity; but not injustice' (Lev., quoted in May, p. 4) he seems to be opening the door to an interpretation of his legal theory as holding some moral procedural limits on law-making or law-enforcing. May argues, that although he is not a strict legal positivist, Hobbes is also not a natural law theorist (as some recent as well as not so recent commentators have suggested), because he does not endorse the notion of substantive law being subject to a moral test. As May puts it, 'the content of the positive law must remain unchallenged in order for the sovereign law-maker to provide the peace and security for which we search.' (p. 121) What Hobbes does allow, according to May, is that 'the procedures by which this content is interpreted and applied is open to critique in terms of the natural law principle of equity. Equity constrains the law-maker' (ibid.) May likens Hobbes's view to that of Lon Fuller and his theory of law as 'procedural as distinguished from a substantive natural law.' (ibid.) He concludes 'Hobbes's views about the limits of law-makers are nearly all procedural, even as they are also connected to his unique view of secular laws of nature. (p. 242) It seems to me that May makes a strong case for Hobbes's treatment of equity as a check on good law-making, which can be compared to Fuller's procedural account.

The other argument I would like to mention briefly is that concerning the rule of law. May argues that Hobbes could be said to embrace, while never fully articulating 'a minimalist notion of the rule of law' (p. 155). This claim is heavily reliant on what Hobbes says in A Dialogue ... where he sets out four criteria of a valid law as: 
1. The command of him or them who have the sovereign power

2. Given to those that be his or their subjects

3. Declaring publicly and plainly

4. What every of them may do, and what they must forbear to do (p. 38/39)

May argues that while the first two are typical expressions of the orthodox view of Hobbesian sovereignty, the second two could be said to provide something much more like a rudimentary notion of the rule of law. He says 'These two requirements taken together form the foundation of various moral and structural limitations on the sovereign: laws will not be valid if they cannot be found and then understood by the people; laws will not be valid if they do not clearly specify what actions lie under the domain of those laws; and laws will not be valid if they are claimed to be retroactively binding.' (p. 39)

These two arguments, first, that Hobbes seems to say that at least one moral principle (equity) should be applied as a (procedural) test for good law and the sovereign is obliged to make good law, and second, that Hobbes in his later life seems to endorse some rudimentary notion of the rule of law are, it seems to me, well made, persuasive and interesting.

The third argument concerning law, is that Hobbes, again relying on $A$ Dialogue ... shows some qualified support for the notion of mixed sovereignty or mixed monarchy. This is partly taken from Hobbes referring to the king-inparliament and commenting about the courts of equity in seventeenth century, England. May claims that 'Hobbes sees these courts as the place where unfairness or arbitrariness, as a matter of iniquity, can be countered, even though not as a matter of injustice. (p. 242) This claim would only have real significance, in my view, if Hobbes could be shown to have also come to support the idea of an independent judiciary, without which, in courts controlled by the king, it seems that when it comes to the crunch, any possible iniquity by the sovereign will be not be subject to any kind of check let alone punishment. And to be fair, May does himself say that Hobbes should have been more receptive to the idea of an independent judiciary.

\section{Concluding Thoughts}

May provides an enlightening and persuasive reading of Hobbes's legal theory as one that is not strictly positivist, nor conventionally natural law but with procedural (moral) limitations on what laws may be made legitimately by the sovereign. Whether this amounts to any genuine limitation on what the sovereign may do, though, is still open to question, in my view. I wonder whether, in 
the end, the argument for limited sovereignty can fully succeed, on the grounds that a self-limiting sovereign is not a truly, substantively, limited sovereign. If there is no person or persons and also no institution, that can question or challenge the sovereign, then the sovereign surely remains the only power and therefore, absolute.

Despite these doubts, I think that Larry May's belief that Hobbes is in some sense not himself a fully committed or a fully consistent absolutist, is right. And I think the book does a great deal of very important work in exploring some of the non-absolutist strains in Hobbes's thought. 